Acta vet. scand. 1969, 10, 181-192.

From the Department of Animal Genetics, Nutrition and Hygiene, Royal Veterinary College, and the Department of Forest Zoology, Royal College of Forestry, Stockholm, Sweden.

\title{
THE MITOTIC AND MEIOTIC CHROMOSOMES OF THE MUSKRAT (ONDATRA ZIBETHICA L.)
}

By

Claes-Göran Kihlberg, Ingemar Gustavsson and Carl Olov Sundt

The muskrat belongs to the subfamily Microtinae and occurred originally only in North-America, particularly in the wellwatered parts of Canada and Alaska. It is valuable as a furred animal with a great capacity of reproduction and was therefore introduced into Europe at the beginning of this century.

The somatic chromosomes of the muskrat have previously been studied by Makino (1953), Matthey (1954) and Moore et al. (1966). Their results deviate from each other as well as from our observations. A tissue culture technique has been used in the study of the somatic chromosomes and a new in vivo technique in the study of the male meiosis.

\section{MATERIAL AND METHODS}

Five individuals, two males and three females, of the brown type and trapped in the north of Sweden were investigated. Nothing was known about the genetic background of the animals. Pieces of lung and kidney were removed for tissue culture as soon as possible after killing the animals with ether. The testes were removed for meiotic studies.

The tissue culture was performed on tissues from four individuals, one male and three females, according to the method described by Basrur et al. (1963). Small pieces of lung and kidney were cut into fragments as small as possible and then put between two cover slips in a Leighton tube. Parker 199 containing $30 \%$ of calf serum was used as tissue culture medium 
and the culture was performed at $38^{\circ} \mathrm{C}$. The medium was changed every day and after a week cell patches could be observed.

The cultures were treated with colchicine in a concentration of $10^{-7} \mathrm{M}$. Three hrs. later the medium was diluted with distilled water to four times its own volume. Twenty min. after this treatment with a hypotonic solution the cells were fixed in three parts of ethanol plus one part glacial acetic acid. After that the cells were stained with acetic orcein and made permanent in Euparal.

Investigation of meiosis was performed in two males according to the method described by Evans et al. (1964) and modified by Hultén et al. (1966). Pieces of testes were carefully cut in a hypotonic solution at $38^{\circ} \mathrm{C}$. The cell suspension was pipetted off and put into tubes, which were incubated at $38^{\circ} \mathrm{C}$ for $20 \mathrm{~min}$. After that the cells were centrifuged down and fixed as above for $30 \mathrm{~min}$. The cells were resuspended, centrifuged down and treated with new fixative. This was repeated several times to get the cells well fixed. Finally the cell suspension was dripped on a slide. After that the preparations were stained in acetic orcein and made permanent.

\section{OBSERVATIONS}

\section{Somatic chromosomes}

A modal chromosome number of 54 was observed in both sexes (Table 1). Most chromosomes had terminal centromeres (Figs. 1 and 2). However, it was not possible to conclude whether they were true $\mathrm{T}$ chromosomes (nomenclature see Levan et al. 1964). Actually in some of them small secondary arms were sometimes observed. The three largest pairs could be identified by size, but remaining pairs showed only small differences in size. A very small distinct arm was observable in one of the largest chromosomes of the male. A similar characteristic was observed in two large chromosomes of the female complement. Only the smallest chromosome pair of both sexes had a median centromere. The second largest pair appeared to have a secondary constriction (Fig. 3). This constriction was not observed in the chromosomes with a distinct secondary arm, however.

\section{Spermatocytogenesis}

Nine spermatogonial metaphases were analysed. In most cells the large chromosomes were located peripherally with their cen- 
T a ble 1 .

\begin{tabular}{|c|c|c|c|c|c|c|c|c|}
\hline \multirow{2}{*}{$\begin{array}{c}\text { Animal } \\
\text { no. }\end{array}$} & \multirow[t]{2}{*}{ Sex } & \multirow[t]{2}{*}{ Tissue } & \multicolumn{5}{|c|}{ Chromosome number } & \multirow{2}{*}{$\begin{array}{c}\text { Cells } \\
\text { counted }\end{array}$} \\
\hline & & & 52 & 53 & 54 & 55 & $\approx 4 \mathrm{n}$ & \\
\hline 1 & $\sigma^{x}$ & $\begin{array}{l}\text { lung } \\
\text { kidney }\end{array}$ & 1 & $\begin{array}{l}3 \\
2\end{array}$ & $\begin{array}{r}23 \\
9\end{array}$ & 2 & 1 & $\begin{array}{l}30 \\
11\end{array}$ \\
\hline 2 & 우 & $\begin{array}{l}\text { lung } \\
\text { kidney }\end{array}$ & 1 & $\begin{array}{l}1 \\
1\end{array}$ & $\begin{array}{l}11 \\
13\end{array}$ & 1 & & $\begin{array}{l}12 \\
16\end{array}$ \\
\hline 3 & 우 & $\begin{array}{l}\text { lung } \\
\text { kidney }\end{array}$ & & 2 & $\begin{array}{r}27 \\
4\end{array}$ & & 1 & $\begin{array}{r}30 \\
4\end{array}$ \\
\hline 4 & $q$ & $\begin{array}{l}\text { lung } \\
\text { kidney }\end{array}$ & & 1 & $\begin{array}{l}6 \\
9\end{array}$ & & & $\begin{array}{r}6 \\
10\end{array}$ \\
\hline $\begin{array}{l}\text { Total for } \\
\text { investigat }\end{array}$ & 11 an & & 2 & 10 & 102 & 3 & 2 & 119 \\
\hline
\end{tabular}

tromeres pointing to the center of the plate and surrounding the small chromosomes (Fig. 4a). Only some of the cells showed a picture similar to that obtained by using colchicine (Fig. 4b).

In leptotene-zygotene (Figs. 4c, d) the sex chromosomes sometimes did not stand out clearly among the thread-like autosomes (Fig. 4c), but mostly they formed a heteropycnotic mass (Fig. 4d).

In early pachytene the sex vesicle became very distinct (Fig. 4e). It was peripherally located and separated from the other chromosomes. However, in some cells the sex vesicle was associated with one of the bivalents (Fig. 6b). Probably this association was fortuitous and caused by stickiness. The associated bivalent did not always seem to be the same. In middle pachytene an internal structure of the sex vesicle could be seen. Later this emerged from the vesicle forming a thread-like loop (Figs. 6c-e). In late pachytene the sex vesicle had disappeared completely, making identification of the sex bivalent impossible (Fig. 4f).

In diplotene only a few cells were observed. Chiasmata could be seen and the centromere regions were observed as heteropycnotic parts of the chromosomes. It was not possible to get an idea about chiasma frequency in all bivalents.

Eighty cells in diakinesis-metaphase I were analysed (Figs. $5 a-d)$. Various types of autosomal bivalents were observed: ring bivalents, cross bivalents and rod bivalents. The sex bivalent was identified without difficulty as the longest one. The sex 
chromosomes were associated end-to-end (Ohno et al. 1957; Geyer-Duszyńska 1963), despiralized and negative heterochromatic in all cells studied. In diakinesis the sex bivalent often had an appearance reflecting its shape in the sex vesicle (Figs. 5a and $6 \mathrm{f}$ ). The associated parts of the sex chromosomes sometimes appeared positive heterochromatic. No dissociation between $\mathrm{X}$ and $\mathrm{Y}$ was ever seen, but the bivalent was intact in all cells studied. One of the autosomal bivalents could be identified by its large size and often had two chiasmata, one located terminally and the other interstitially (Fig. 5a). The stage of terminalization varied in the other bivalents. Small bivalents were terminalized earlier than the larger ones, and in a few cells some of the smallest bivalents were dissociated before the largest were terminalized (Fig. 5d).

No cell in anaphase could be found, and this was not to be expected as the cells had been treated with a hypotonic solution.

Eighteen cells in metaphase II were analysed (Figs. 5e,f). All of them had 27 chromosomes. The chromosomes were spiralized and the chromatids diverging. Only one of the chromosomes could be identified with certainty. It was the small chromosome with a median centromere.

Some "polyploid" cells were observed. They were all in metaphase I and metaphase II except one, which was in diplotene. No multivalents were observed.

\section{DISCUSSION}

The chromosome number of the individuals studied agrees with that previously observed. According to Matthey (1954) the $\mathrm{X}$ chromosome has a median centromere. Such an X chromosome has not been found in this investigation. Matthey also concluded that all autosomes were one-armed. Our observations point to the fact that the smallest autosomal pair has a median centromere. The same thing was found by Makino (1953) and Moore et al. (1966), although the former was not able to identify the $\mathrm{X}$ chromosome. Moore et al. found the $\mathrm{X}$ chromosome to be one of the largest of the complement although they could not distinguish it from the large autosomes. On the basis of our observations the N.F. value (the number of major chromosome arms) was determined to be 56. Although the $\mathrm{Y}$ chromosome could not be identified in somatic cells, observations of male meiosis show that it is one of the smallest one-armed chromo- 
somes. On the other hand, the $\mathrm{X}$ chromosome of the somatic complement is in all probability the large chromosome with a distinctly recognizable secondary arm. This statement should be made with great caution, however, since the secondary arm is heterochromatic. Heterochromatic regions often show a great variability in appearance due to allocycli. Loss of such regions has also been considered to be easily tolerated as they contain polygenes (Mather 1943).

Bender and Chu (cited by Klinger 1963) propose that the relative number of two-armed chromosomes is great in highly specialized species. According to this theory Ondatra zibethica must be considered as a primitive species. However, its way of living suggests that it is a specialized form of Microtinae.

\section{REFERENCES}

Basrur, P. K., V. R. Basrur \& J. P. W. Gilman: A simple method for short term cultures from small biopsies. Exp. Cell. Res. 1963, $30,229-232$.

Evans, E. P., G. Breckon \& C. E. Ford: An air-drying method for meiotic preparations from mammalian testes. Cytogenetics 1964, $3,289-294$.

Geyer-Duszyniska, I.: On the structure of the XY bivalent in Mus musculus L. Chromosoma (Berl.) 1963, 13, 521-525.

Hultén, M., J. Lindsten, Pen-Ming L. Ming \& M. Fraccaro: The XY bivalent in human male meiosis. Ann. hum. Genet. 1966, 30, $119-123$.

Klinger, $H$. P.: The somatic chromosomes of some primates (Tupaia glis, Nycticebus cousang, Tarsius bancanus, Cercocebus aterrimus, Symphalangus syndactylus. Cytogenetics 1963, 2, 140—151.

Levan, A., K. Fredga \& A. A. Sandberg: Nomenclature for centromeric position on chromosomes. Hereditas (Lund) 1964, 52, 201-220.

Makino, S.: Chromosome numbers of some American rodents. Science $1953,118,3073$.

Mather, K.: Polygenic inheritance and natural selection. Biol. Rev. $1943,18,32-64$.

Matthey, R.: Nouvelles recherches sur les chromosomes des Muridae. (New investigations in the chromosomes of the Muridac). Caryologia 1954, 6, 1-44.

Moore, Jr., Wellington, R. L. Elder \& L. J. Gillespie: The chromosomes of the muskrat. J. Hered. 1966, 57, 104.

Ohno, S., W. D. Kaplan \& R. Kinosita: Note on non-chiasma-type association between the $\mathrm{X}$ and $\mathrm{Y}$ chromosomes of Drosophila melanogaster and Mus musculus. Exp. Cell Res. 1957, 13, 422—424. 


\section{SUMMARY}

The chromosome number of the muskrat (Ondatra zibethica L.) was determined to be 54 in an investigation of the mitotic and meiotic chromosomes. All chromosomes are one-armed with the exception of one small pair which is biarmed. Further, the $\mathrm{X}$ chromosome, one of the largest of the complement, seems to have a small secondary arm making possible an identification of the pair. A systematic investigation of the chromosomes, and especially the sex chromosomes at different stages of the spermatocytogenesis, has been performed.

\section{ZUSAMMENFASSUNG}

Die Mitos- und Meioschromosomen der Bisamratte (Ondatra zibethica L.).

Bei einer Untersuchung der Mitos- und Meioschromosome der Bisamratte wurde festgestellt, dass die Chromosomzahl 54 sei. Sämtliche Chromosomen sind einarmig mit Ausnahme von einem kleinen Paar welches zweiarmig ist. Ausserdem scheint das X-Chromosom, eines von den grössten Chromosomen des Komplements, einen kleinen sekundären Arm zu haben, der die Identifizierung des Paares ermöglicht. Eine systematische Untersuchung der Chromosomen und besonders die der Geschlechtschromosomen in verschiedenen Stadien der Spermatocytogenesis, ist ausgeführt worden.

\section{SAMMANFATTNING}

Mitos- och meioskromosomerna hos bisamråtta (Ondatra zibethica L.).

Kromosomtalet hos bisamråtta (Ondatra zibethica L.) bestämdes till 54 vid undersökning av mitos- och meioskromosomerna. Samtliga kromosomer är enarmade med undantag av ett litet par, som är tvåarmat. Dessutom synes X-kromosomen, en av de största kromosomerna i komplementet, ha en liten sekundär arm, som möjliggör en identifiering av paret. En systematisk undersökning av kromosomerna och i synnerhet könskromosomerna under olika stadier av spermatocytogenesen har utförts.

(Received December 5, 1968). 


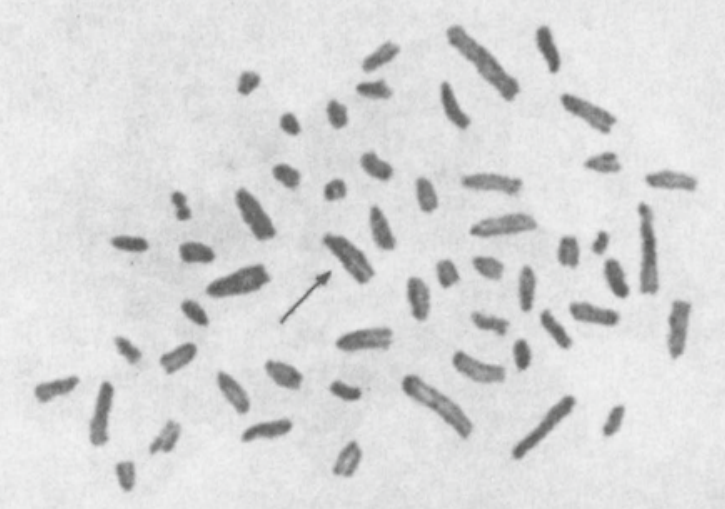

\section{1}

\section{0}

- $1.10 \mu$

Figure 1. Somatic chromosomes of the male muskrat.

The $\mathrm{X}$ chromosome at the arrow. 


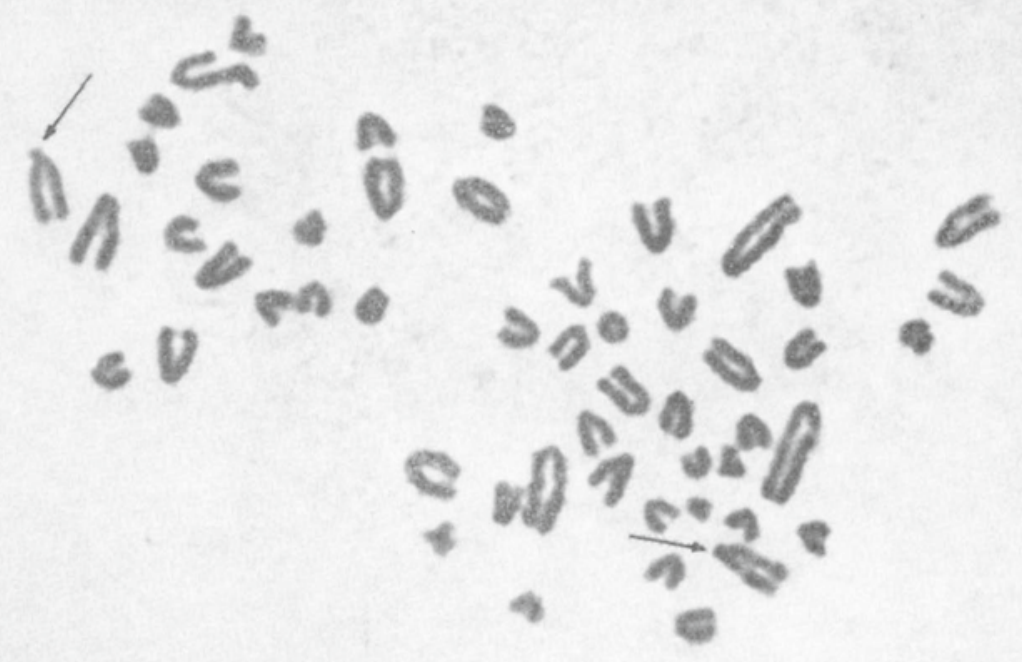

\section{$\backslash$

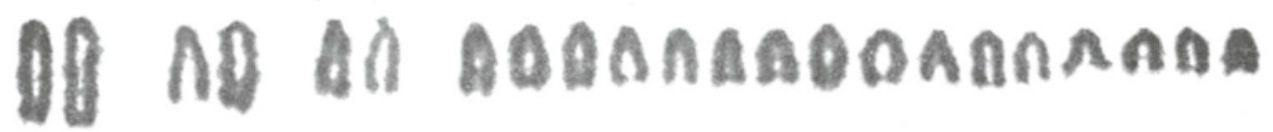

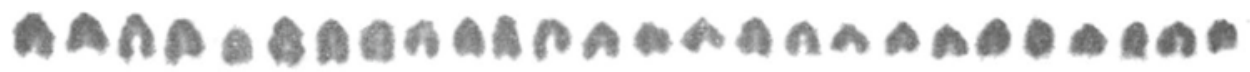

A $A$ 웅

Figure 2. Somatic chromosomes of the female muskrat. The $\mathrm{X}$ chromosomes at the arrows. 

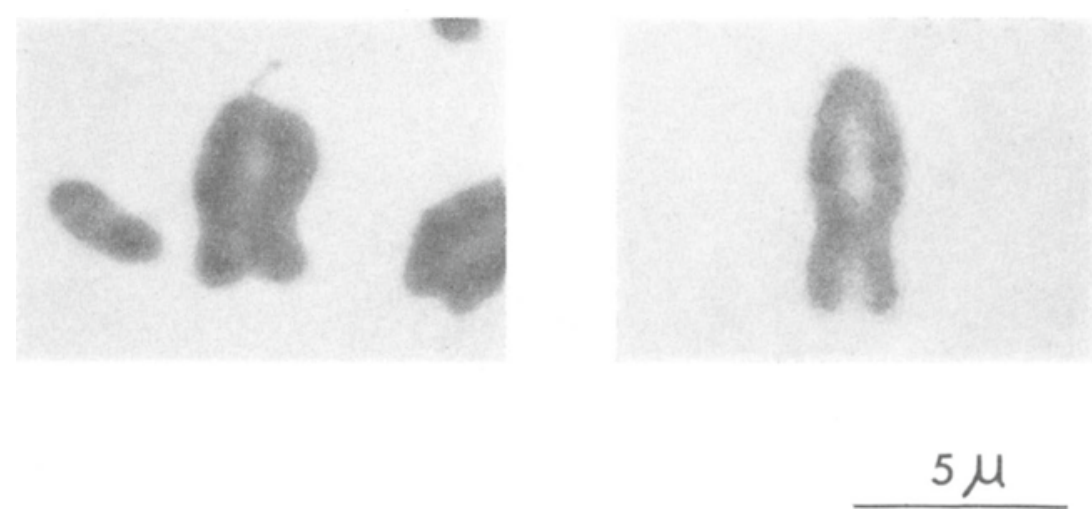

Figure 3. Chromosomes from the two different cells exhibiting secondary constriction.

Figure 4 .

a: spermatogonial metaphase relatively undisturbed by the hypotonic pretreatment, showing a typical picture of a metaphase.

b: spermatogonial metaphase affected by the hypotonic pretreatment with a picture similar to that of a cell treated with colchicine.

c: leptotene-zygotene. No sex vesicle can be identified.

$\mathrm{d}$ : leptotene-zygotene. The sex vesicle is identifiable as a heteropycnotic mass peripherally located (arrow).

e: pachytene. The sex vesicle peripherally located with a thread-like loop emerging (arrow).

$\mathrm{f}$ : late pachytene. The sex vesicle has disappeared and the sex bivalent cannot be distinguished from the autosomal bivalents. 


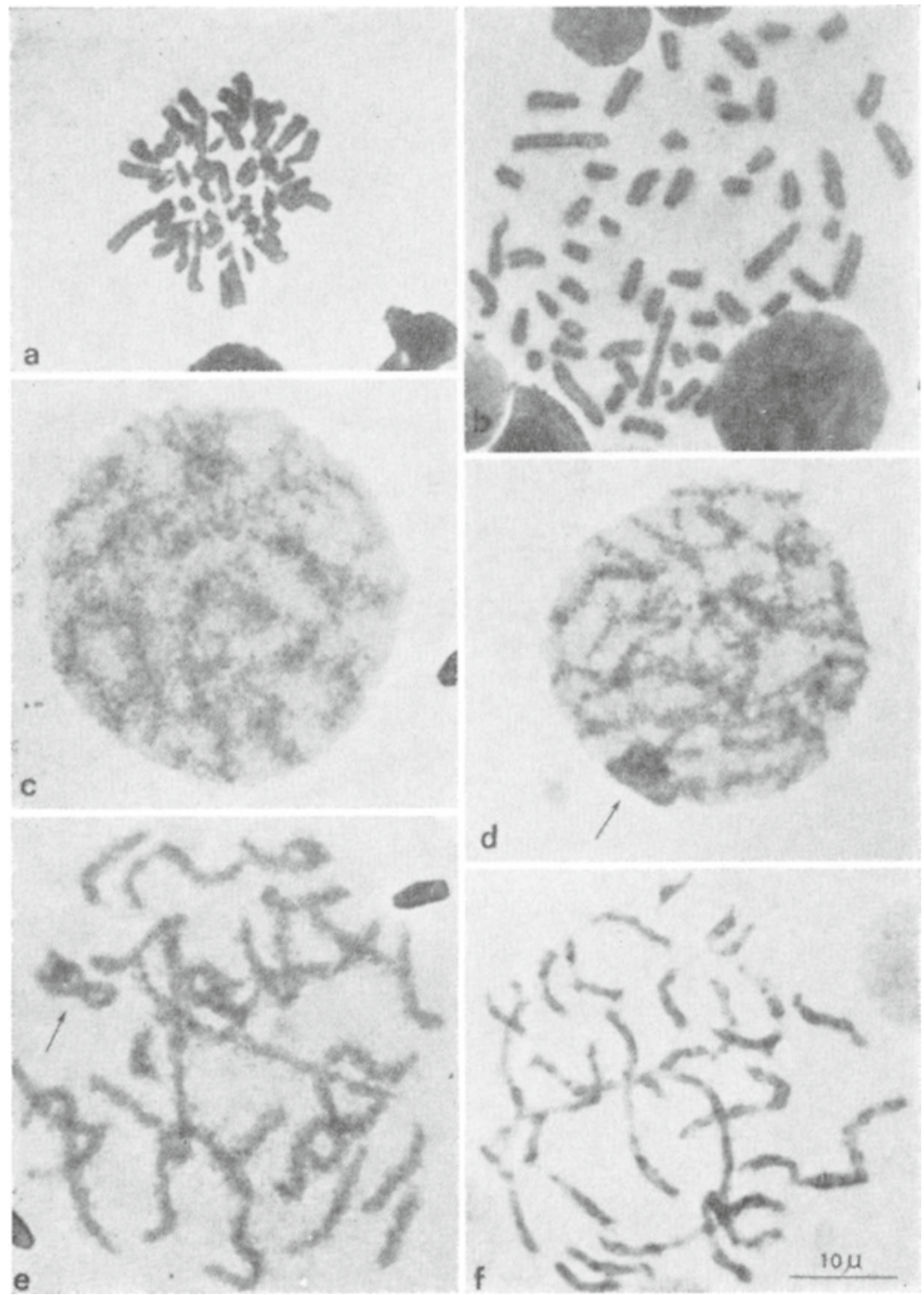

Figure 4. 


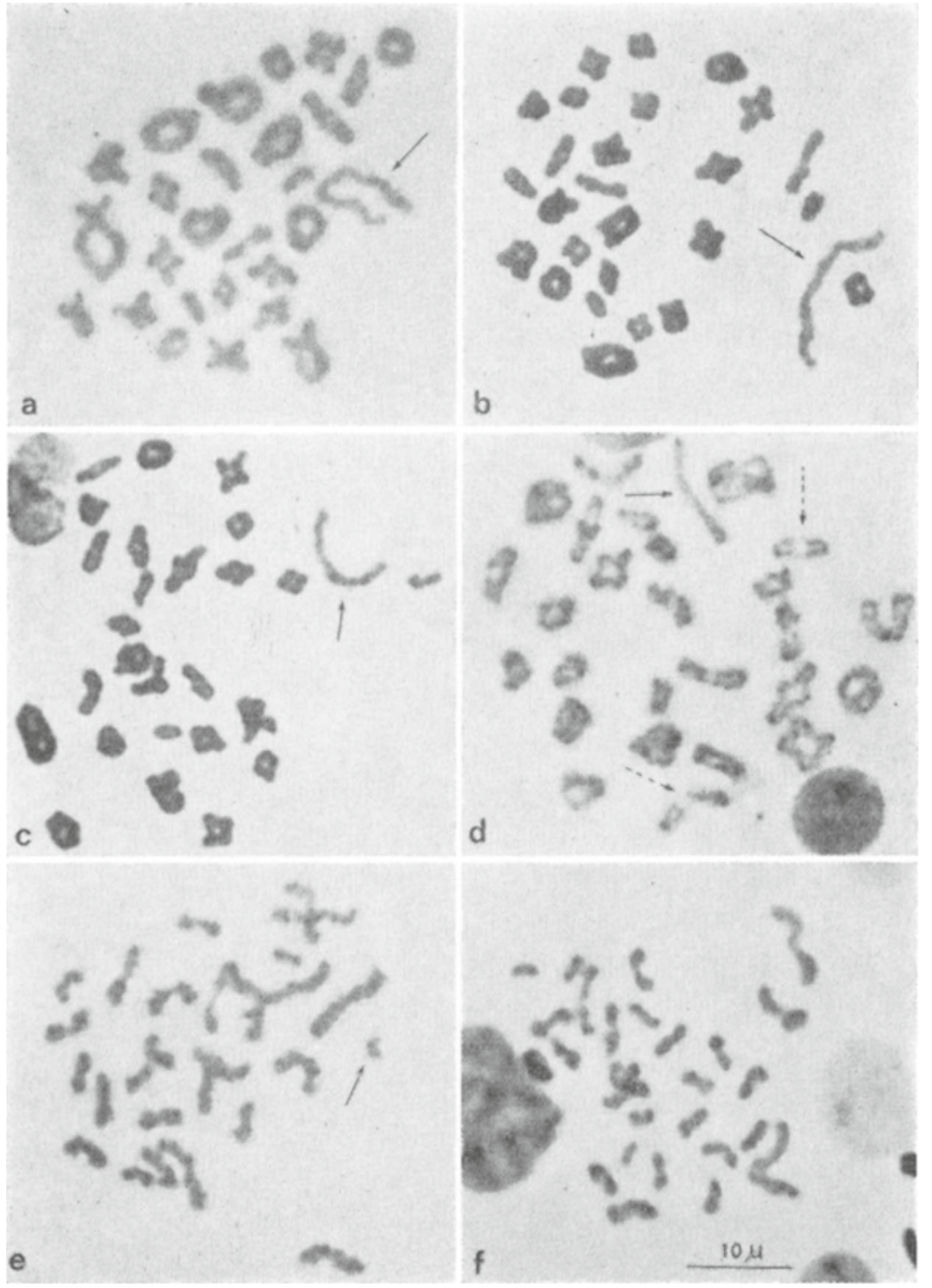

Figure 5 .

a-d: diakinesis-metaphase $I$. The filled arrows point to the sex bivalent. Note dissociated small bivalents (dashed arrows) of Fig. 5d.

e-f: metaphase II. Note small chromosome with median centromere (arrow). 

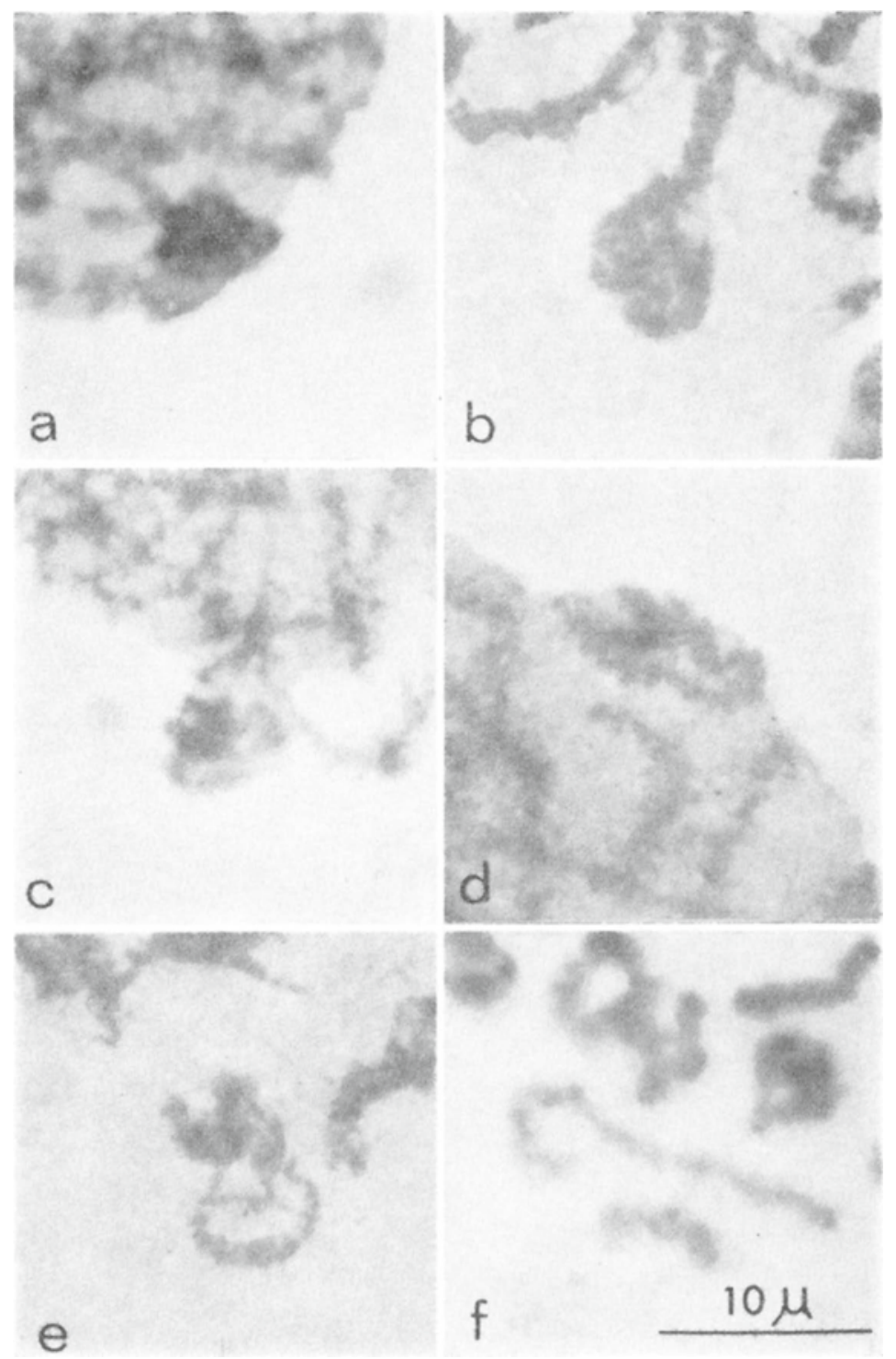

F i g u r e 6. A pictorial analysis of the sex chromosomes in prophase I (a-e) and diakinesis (f) of the male meiosis.

a: The heteropycnotic sex vesicle peripherally located as a distinct body with no visible internal structure.

b: The sex vesicle with visible internal structure attached to one autosomal bivalent.

c-e: Different stages in the emergence of the sex bivalent from the sex vesicle.

f: The sex bivalent in diakinesis still reflecting its appearance in the prophase. 